\title{
A History of The Six-Year Primary Project in the Use of Yoruba as the Medium of Primary Education
}

Toyin Falola

University of Texas at Austin

toyinfalola@austin.utexas.edu

Michael Oladejo Afolayan

M\&P Educational Consulting International

Osogbo, Nigeria and Springfield, Illinois

mafolayan@yahoo.com

\section{The Larger Context and Arguments on Mother Tongue and Education}

Many non-English speaking parents think that if their children only learn English, they will fare better in school. In the last half a century or so, researchers have noticed the problem faced especially by developing nations in their language-related educational policies. ${ }^{1}$ Some countries, like Burundi, for example, have adopted this mentality and made English the official national language, in hopes that encouraging English will stimulate the economy and improve the job prospects of youth. ${ }^{2}$ However, research consistently shows that focusing entirely on English or any "majority language" at the detriment of one's native language actually does more harm than good. There are many

1 See works of Joshua Fishman, Language Problems of Developing Nations. New York: Wiley, 1968 and Joshua Fishman. Readings in the Sociology of Language. The Hague, Paris: Mouton, 1968.

2 Angelina Kioko, "Why Schools Should Teach Young Learners in Home Language," British Council, January 16, 2015, https://www.britishcouncil.org/voices-magazine/ why-schools-should-teach-young-learners-home-language. 
benefits of children's maintaining their native language, which I summarize below and will expand upon throughout the essay: ${ }^{3}$

1. One's language is tied with one's identity. Consequently, then, maintaining one's native language means maintaining one's identity. With this maintained identity, one feels a connection to one's native culture and therefore has a positive self-concept.

2. Maintaining one's language allows one to strengthen relationships with family and community members who perhaps do not speak English (or the majority language) or who prefer to speak in their native language. This allows for one to keep a reliable social network bound by a common tongue.

3. If a young child is forced to speak in English (or the majority language) when they prefer to speak in their mother tongue, they are also forced to operate at a lower intellectual age than they actually are. This can damage the child's academic future. Therefore, it is best for the child to be encouraged to speak both languages and experience the benefits of bilingualism and a fully developing brain.

4. Similar to \#3, children who are able to speak in their native language and English (or the majority language) experience higher academic achievement throughout their life.

Many of these points and more have been promoted by influential groups. Since 1953, UNESCO has expressed great support for formal instruction in children's native languages. Today, UNESCO has cited evidence of the many advantages of learning in one's native tongue: ${ }^{4}$

1. Children will be more likely to enter into and succeed in school. ${ }^{5}$

2. Parents will be better able to interact with their children's teachers and take an active role in their children's learning. ${ }^{6}$

3 International Development Research Association, "Why Is It Important to Maintain the Native Language?” IDRA, January 2000, https://www.idra.org/resource-center/ why-is-it-important-to-maintain-the-native-language.

4 Jessica Ball, "Children Learn Better in Their Mother Tongue," Global Partnership for Education, February 21, 2014. https://www.globalpartnership.org/blog/ children-learn-better-their-mother-tongue.

5 Kimmo Kosonen, Education in Local Languages: Policy and Practice in Southeast Asia. First Languages First: Community-Based Literacy Programmes for Minority Language Contexts in Asia (Bangkok: UNESCO Bankok, 2005), as cited in Ball, "Children Learn Better in Their Mother Tongue."

6 Carolyn J. Benson, "Real and Potential Benefits of Bilingual Progammes in Developing Countries," International Journal of Bilingual Education and Bilingualism 5, no. 6 
3. Girls and rural children are more likely to advance through school grades at the typical rate if they are not inundated with their non-native language. ${ }^{7}$

4. Children who participate in multilingual programs show more advanced thinking skills than do their peers who participate in monolingual programs. ${ }^{8}$

\section{First Language Skills Improving Second Language Skills}

In the United States, $21 \%$ of children come from homes where English is not the primary language used. It is estimated that, by $2030,40 \%$ of children will come from non-English speaking homes. Also that same year, it is estimated that $71 \%$ of these non-English speaking homes will be Spanish-speaking homes. ${ }^{9}$ However, in spite of these facts, most schools in the United States instruct students exclusively in English (with the exception of foreign language classrooms), which means that non-English speaking students will struggle to communicate with their English-speaking peers and teachers. ${ }^{10}$ This is also problematic, given how about two-thirds of children in the United States with limited English proficiency come from homes with limited income, thus increasing the likelihood of academic struggle. ${ }^{11}$ Indeed, statistical research has consistently shown that students (Spanish-speaking

(2002): 303-317, as cited in Ball, "Children Learn Better in Their Mother Tongue."

7 Mart Hovens, "Bilingual Education in West Africa: Does It Work?" International Journal of Bilingual Education and Bilingualism, 5, no. 5 (2002): 249-266, and UNESCO Bangkok, Advocacy Brief on Mother Tongue-Based Teaching and Education for Girls (Bangkok: UNESCO, 2005), as cited in Ball, "Children Learn Better in Their Mother Tongue."

8 Ellen Bialystok, Bilingualism in Development: Language, Literacy, and Cognition (Cambridge: Cambridge University Press, 2001); Jim Cummins, Language, Power and Pedagogy (Clevedon, UK: Multilingual Matters, 2000); and Kendall A. King and Alison Mackey, Bilingual edge: Why, When, and How to Teach Your Child a Second Language (New York: Collins, 2007), as cited in Ball, "Children Learn Better in Their Mother Tongue."

9 National Center for Education Statistics, The Condition of Education 2010 (Rep. No. NCES 2010-028), 2010, and Wayne P. Thomas and Virginia P. Collier, A National Study of School Effectiveness for Language Minority. Students' Long-Term Academic Achievement, 2002, as cited in Francisco Palermo et al., "Cross-Language Associations and Changes in Spanish-Speaking Preschoolers' English and Spanish Academic Abilities," Applied Psycholinguistics 38, no. 2 (2017): 347.

10 Palermo et al., "Cross-Language Associations," 347-348.

11 Capps et al., The New Demography of America's Schools: Immigration and the No Child Left Behind Act, 2005, and Michael J. Kieffer, "Early Oral Language and Later Reading Development in Spanish-Speaking English Language Learners: Evidence from a NineYear Longitudinal Study," Journal of Applied Developmental Psychology 33, no. 3 (2012): 146-157, as cited in Palermo et al., "Cross-Language Associations," 348. 
students in particular) with limited English skills are less likely to graduate high school than their English-speaking peers (62\% versus 82\% for the 20132014 academic term). ${ }^{12}$ To add to this misfortune, currently throughout the world, there are 50 to 75 million children who are educationally marginalized (or unable to attend school) because they do not speak the majority language of their local school. ${ }^{13}$ This undoubtedly presents some inequity issues. If children in school are told to only speak in English (which very well may be the national language), then urban children who have already spoken or been exposed to English have an advantage over rural children.

While one may initially think that the obvious solution is to teach non-English speaking children English as soon and as thoroughly as possible, researchers actually propose another solution. They argue that many of these epidemics could be solved if non-English speaking (or non-majority-language speaking) children were taught in their own mother tongue, for the evidence shows time and time again that learning and speaking in one's mother tongue at a young age vastly improves education opportunity. Studies also show that children who are taught in their native language are more confident and academically successful, and children who are not taught in their native language are more likely to experience more academic failure and drop out of school. ${ }^{14}$ Children allowed to speak in their mother tongue and children taught in their mother tongue have more positive attitude toward schooling and a better understanding of the school curriculum, for two reasons: ${ }^{15}$

1. Being able to speak in their mother tongue allows children to feel more comfortable in their first-ever days of school. Everything in the school environment will be foreign to them enough, but having access to the familiarity of their native language will give them some buffer as they ease into a new situation.

2. The children will be more comfortable interacting with others in a school setting. They will be more confident in their ability to ask and answer questions. They will also be able to ponder over what they are learning. This then allows the children to see how school is relevant in their lives.

Conversely, then, not being able to speak in the mother tongue and not being taught in the mother tongue places children in isolation and abject

12 US Department of Education. Ed Data Express: Data About Elementary and Secondary Schools in the U.S., 2005, as cited in Palermo et al., "Cross-Language Associations," 348.

13 Ball, "Children Learn Better in Their Mother Tongue."

14 Ibid and Ball, "Children Learn Better in Their Mother Tongue."

15 Kioko, "Why Schools Should Teach Young Learners in Home Language." 
disadvantage. They will not be able to thrive in an environment of mutual interaction and engagement. They also will not be as readily able to express their creativity and imagination. In short, they will not have the advantages that other students who speak the dominant language have, and this will dampen certain students' enthusiasm for learning. Teachers who do not speak certain students' mother tongue will also be at a disadvantage, for they will not be as capable in communicating with them. It is also worth noting that being instructed in the mother tongue builds better literacy. Because the children are able to understand the language being spoken in the classroom, they are also better able to associate sounds with written letters that form words. Consequently, the better they understand the language of instruction, the faster they will be able to establish essential reading skills that will give them a solid foundation for the rest of their academic career. ${ }^{16}$

Furthermore, even if non-English speaking (or non-majority-language speaking) children are later to learn English (or the majority language), research shows that the skills learned in the native tongue can transfer to the learning of a second language. This means that "a learner who knows how to read and write in one language will develop reading and writing skills in a new language faster." ${ }^{17}$ For instance, a non-native English learner will already know from prior experience that certain sounds are associated with different letters. It will not be difficult, then, to transfer this concept to English: certain English sounds are associated with certain English letters. This means that, contrary to popular opinion, being fluent in the native tongue as a child will not delay the English learning process. ${ }^{18}$

All of the facts above relate to the "interdependence hypothesis," which says that skills learned from one's first language can transfer to one's second language while it is being learned. ${ }^{19}$ Most transferrable are skills related to higher-order thinking, like math and literacy. ${ }^{20}$ However, it is worth noting that even less easily transferrable skills like syntax and phonetics are more easily transferrable among languages like Spanish, Portuguese, and English due to their structural similarities. This means that English-speaking school

16 Ibid.

17 Ibid.

18 Ibid.

19 James Cummins, "Linguistic Interdependence and the Educational Development of Bilingual Children," Review of Educational Research, 49 (1979): 222-251; James Cummins, Language, Power, and Pedagogy: Bilingual Children in the Crossfire (Buffalo: Multilingual Matters, 2000); Johanne Paradis, Fred Genesee, and Martha B. Crago, Dual Language Development and Disorders: A Handbook on Bilingualism and Second Language Learning (Baltimore: Brookes, 2010), as cited in Palermo et al., "Cross-Language Associations," 349.

20 Palermo et al., "Cross-Language Associations," 349. 
settings that allow, for example, for Spanish-speaking children to learn and speak in their native language will have better experiences of transfer when they learn English. ${ }^{21}$ Conversely, English-speaking school settings that deny Spanish-speaking students the opportunity to learn and speak in their native language undermine these children's potential. But there is a caveat: studies have also found that Spanish-positive English-speaking school settings are only effective if the Spanish-speaking students have a solid foundation in their native language. In other words, Spanish-speaking children only experience true benefits if they have been allowed to speak and learn in their native language effectively and without many limitations. ${ }^{22}$ One thing that would be lost in situations where children are denied the freedom to use their mother tongues at school is the prior knowledge they bring to the classroom, a skill that triggers automaticity, and this is a pertinent factor in the cognitive process.

\section{Language, Identity, and Culture}

Identity and culture are intimately linked because culture encompasses "the totality of [one's] being ... values ... and beliefs" 23 passed on for generations. Culture involves one's religion, food, clothing, celebrations, and understandings of the world. ${ }^{24}$ Language and culture are also intimately linked, which means that language and identity are intimately linked. ${ }^{25}$ Ultimately,

21 Diane August et al., "The Critical Role of Vocabulary Development for English Language Learners," Learning Disabilities Research \& Practice 20 (2005): 50-57; Ellen Bialystok, Gigi Luk, and Ernest Kwan, "Bilingualism, Biliteracy, and Learning to Read: Interactions among Languages and Writing Systems," 9, no. 1 (2005): 43-61; Conxita Lleó et al., "Syllable Final Consonants in Spanish and German Monolingual and Bilingual Acquisition," in (In)vulnerable Domains in Multilingualism, ed. Natascha Müller (Amsterdam: John Benjamins, 2003), 191-220, as cited in Palermo et al., "Cross-Language Associations," 349.

22 Anny Patricia Castilla, Maria Adelaida Restrepo, and Ana Teresa Perez-Leroux, "Individual Differences and Language Interdependence: A Study of Sequential Bilingual Development in Spanish-English Preschool Children," International Journal of Bilingual Education and Bilingualism 12, no. 5 (2009): 565-580, and Carla Wood Jackson, Christopher Schatschneider, and Lindsey Leacox. "Longitudinal Analysis of Receptive Vocabulary Growth in Young Spanish English-Speaking Children from Migrant Families," Language, Speech, and Hearing Services in Schools 45, no. 1 (2014): 40-51, as cited in Palermo et al., "Cross-Language Associations," 351.

23 Sandra Patricia Mercuri, "Understanding the Interconnectedness between Language Choices, Cultural Identity Construction and School Practices in the Life of a Latina Educator," Gist Education and Learning Research Journal 6 (2012): 14.

24 Lilia D. Monzó and Robert Rueda, "Passing for English Fluent: Latino Immigrant Children Masking Language Proficiency," Anthropology \& Education Quarterly 40, no. 1 (2009): 20-40, as cited in Mercuri, "Understanding the Interconnectedness," 14.

25 Mercuri, "Understanding the Interconnectedness," 14. 
the result is a triangle of culture-identity-language. Language is a critical part of this triangle because language allows for the communication of values and beliefs, as well as a sense of group identity, to occur. ${ }^{26}$ Consequently, then, losing language feels like one has lost one's culture and oneself. ${ }^{27}$ According to Trueba,

Language is one of the most powerful human resources needed to maintain a sense of self-identity and self-fulfillment. Without a full command of one's own language, ethnic identity, the sharing of fundamental cultural values and norms, the social context of interpersonal communication that guides interactional understandings, and the feeling of belonging within a group are not possible. ${ }^{28}$

If an individual loses a connection to their heritage language, they may lose the funds of knowledge - or bodies of knowledge that have been historically and culturally crafted and preserved for group for personal well-being and guidance $^{29}$ - that their community has carried for generations. ${ }^{30}$

Many languages - and their associated cultures and identities - are indeed dying out. In the United States alone, it is estimated that by 2024, only 50 indigenous languages will remain out of the 175 that exist today. ${ }^{31}$ It is also estimated that, within the next 100 years, $90 \%$ of the world's 7,000 languages will die. ${ }^{32}$ All of this comes at a tremendous price - mostly that with the death of language also comes the death of history and knowledge of a diverse group

26 M. Bakhtin, "Discourse in the Novel” in The Dialogic Imagination: Four Essays, ed. M. Bakhtin (Austin: University of Texas, 1981), 259-422.

27 Colin Baker, Foundations of Bilingual Education and Bilingualism, 3rd ed. (Clevedon: Multilingual Matters, 2001).

28 Henry T. Trueba, "The Relevance of Theory on Language and Culture with Pedagogical Practices," in Language and Culture in Learning: Teaching Spanish to Native Speakers of Spanish, eds. J. Merino, Henry T. Trueba, and Fabián A. Samaniego (Washington, D.C.: The Falmer Press, 1993), 259.

29 Luis C. Moll, "Bilingual Classroom Studies and Community Analysis: Some Recent Trends," Educational Researcher 21, no. 2 (1992): 20-24.

30 Mahera Ruby, "The Role of a Grandmother in Maintaining Bangla with her Granddaughter in East London," Journal of Multilingual and Multicultural Development 33, no. 1 (2012): 67-83.

31 Olivia Bradley, "Understanding the Importance of Native-Language Instruction," The Borgen Project, October 30, 2017, https://borgenproject.org/ importance-native-language-instruction/.

32 Lance Wallace, "What's Lost When a Language Dies," The Guardian, November 10, 2009. https://www.the atlantic.com/national/archive/2009/11/ whats-lost-when-a-language-dies/29886/. 
of individuals. Dr. Pamela Cote summarized the tragedy of the death of language aptly:

The diversity of our languages represents the richness of Being ... [This is] why the loss of a language is such a concern and why minority rights are such an emotionally charged issue ... Because language discloses cultural and historical meaning, the loss of language is a loss of that link to the past. Without a link to the past, people in a culture lose a sense of place, purpose, and path; one must know where one came from to know where one is going. The loss of language undermines a people's sense of identity and belonging, which uproots the entire community in the end. ${ }^{33}$

This severity of the death of "place, purpose, and path" cannot be overstated. If we as a global society believe in preserving the sanctity of individuals and the diversity of the human race, we must allow our children to speak their native language, even if that native language is not the majority language of a particular region. If we do not encourage children to speak their native language in school or if we shame children for speaking their native language in school, they will grow into adults who are disconnected from their history (and, consequently, their identity). There will also be a tremendous loss of culture and heritage worldwide. Conversely, then, if we establish programs and plans that allow children to speak their own native language in school, they will not only more easily acquire a second language (as elucidated above) but also maintain their connections to their past. In turn, the world will still possess a pool of knowledge repertoire that expresses a rich diversity and history.

\section{The Yoruba Experiment in Mother Tongue Education (MTE)}

One of the most radical educational experiments in Africa in the last half of one century was the Six-Year Primary Project of the then University of Ife (now Obafemi Awolowo University), Ile-Ife, Nigeria. This was based on the use of Yoruba as the language of instruction. It was a model that generated a great deal of controversies in the 1970s. Predicated on the assumption that no language would provide the child with adequate cognitive locus standi like the mother tongue, be it as the medium of instruction or as the medium of acquisition of knowledge. This was a theoretical framework that has been accentuated strongly in works of scholars like J. Ball (2010) ${ }^{34}$ in which cognitive

33 Ibid.

34 See J. Ball, Enhancing Learning of Children from Diverse Language Backgrounds: Mother Tongue-based Bilingual or Multilingual Education in the Early Years. Paris: UNESCO. 
abilities in children with backgrounds in bilingualism and even multilingualism are said to be enhanced by their strong mother tongue education backgrounds and knowledge base. Other scholars have held the same position over the years. For example, twenty-two scholars in the pivotal work of Benson and Kosonen $(2013)^{35}$ support the same model, demonstrating that it has been proven around the world that when local minority languages of students are integrated into classroom instructions, students tend to perform better in knowledge acquisition and demonstrated higher order of cognition. The superimposition of a single language of instruction at the expense of the child's local language has a defeatist tendency in the learner's psyche. Jim Cummins $(2013)^{36}$ argues strongly against this model as it does not help minority students in learning environments. Ball and Mclvor (2013) ${ }^{37}$ support this line of thinking in their examination of the situation in Canada. In fact, according to UNESCO studies (2016), ${ }^{38}$ the child is at a major disadvantage when the language of instruction is outside the mother tongue of that child and he or she is psychologically put in a position of a stranger in the classroom.

The implications of mother tongue education are, as could only be expected, a big issue in the larger picture of educational instruction and sociology of learning. The Yoruba experiment came at such a time when the nation had been engaged in a decade-long series of debates to rid itself of the cumbersome colonial burden of a retrogressive colonial language educational policy. Yet, it was not without its critics. Agbo Ologunde (1982), for example, accentuates the problems that such experimentation faced both at the state and at the national levels. They were: "national unity, personnel, finance, and parental wishes." 39 Many proponents of African liberations have spoken for the use of indigenous pedagogies to solve its crisis of a lack of scientific and technological breakthroughs. In the constituents of power, language is central. For

35 C. Benson, C., \& K. Kosonen, K. (Eds.) (2013). Language Issues in Comparative Education: Inclusive Teaching and Learning in Non-Dominant Languages and Cultures. Rotterdam: Sense Publishers.

36 J. Cummins, Fundamental psycholinguistic and sociological principles underlying education success for linguistic minority students. In T. Skutnabb-Kangas, R. Phillipson, A. Mohanty, \& M. Panda (Eds.). Social Justice Through Multilingual Education (pp. 19-35). Clevedon, UK: Multilingual Matters.

37 Canada's big chill: Indigenous languages in education. In C. Benson \& K. Kosonen (Eds.). Language Issues in Comparative Education: Inclusive Teaching and Learning in Non-Dominant Languages and Cultures. (pp. 19-38). Rotterdam: Sense Publishers, 1981.

38 UNESCO, "If you don't understand, how can you learn?" Global Education Monitoring Report, Policy Paper 24. UNESCO: Paris, 2016.

39 See Agbo Ologunde, in Adebisi Afolayan (Ed.), Yoruba Language and Literature. Ibadan \& Ife: University Press Limited and University of Ife Press, 1982, p. 287. 
example, Molefi Asante (1995), ${ }^{40}$ among the strongest proponents of the Africanist model of the last century and of the current century argues that the language of our knowledge and of existence must not be a residue of our imperialist past. He writes:

An ideology for liberation must find its existence in ourselves, it cannot be external to us, and it cannot be imposed by those other than ourselves; it must be derived from our particular historical and cultural experience. Our liberation from the captivity of racist language is the first order of the intellectual. There can be no freedom until there is a freedom of the mind. As Lorenzo Turner understood, language is essentially the control of thought. It becomes impossible for us to direct our future until we control our language. ${ }^{41}$

The centrality of language to cognition and education makes it crucial for mother tongue instruction to engage the mind of its progressive policy makers and intellectuals. This engagement informs the Ife project. Afolayan Adebisi $(1970)^{42}$ and his team of scholars focused on the implementation of the SixYear Primary Project. In his write-up, Afolayan identifies four problems that faced his team of experts, who were selected from various fields: The provision of an adequate syllabus; the availability of adequate textbooks; the supply of adequate teachers; and experimental and technical difficulties. All these differ a great deal from even a more complicated issue of political will, some of which Ologunde addressed. The political will as well as anachronistic views of consumers, especially parents, who were already ingrained into the culture of total dependency on the colonial education and what it considers as the retrogressive and delimiting factors of a mother tongue education for their children, militated against the embrace of mother tongue education. The Afolayan report shows that in fact, the Institute of African Studies offered Yoruba language instructions to train teachers who would be involved in the implementation stage of the project. A syllabus was designed titled, "Suggested Syllabus for Yoruba" in which two objectives were identified. They are:

\section{a. Permanent literacy; and}

40 Molefi K. Asante, Afrocentricity. Trenton, NJ: Africa World Press, Inc., 1995.

41 Ibid. p31

42 Adebisi Afolayan, "The Six-Year Primary Project in the Use of Yoruba as the Medium of Primary Education: A Project of the Institute of Education of the University of Ife, Ile-Ife, Nigeria, in Collaboration with the Ford Foundation, the Western State Ministry of Education, the Local School Board, and All Available Scholars of Yoruba and English Studies." Unpublished, p1. 
b. Ability to use Yoruba effectively - whether in the speech situation or in reading and writing - as a tool not only for self-expression but for learning. ${ }^{43}$

The Six-Year Primary Project sadly did not go beyond the initial experimental stage and never experienced implementations at any appreciable large scale known to us. Yet, it was not a wasted effort because among the products of the experiments were some of the finest professionals uniquely endowed in their individual calls of life. Chief among those success stories is the famous musician, saxophonist and choreographer popularly known as Lagbaja, whose unique model of musical performance and theatricality has been non-peril in the Black world. There are engineers, physicians, creative teachers, etc., uniquely endowed to reflect the exceptionality and matchlessness of their special skills which those not exposed to the mother tongue pedagogy could not pull off.

Since the excitement generated by this half a century-old mother tongue education experiment, there have been various attempts to provide instructional materials purely to reflect the unique quality of this model. Take for example, a proponent of the Mother Tongue Education (MTE), a career engineer, Dr. Kayode J. Fakinlede has made several attempts at providing instructional materials based purely on the MTE. One of his most notable efforts is the book titled, İwé İmọ İjìnle Ė kínní Ni È dè Yorùbá, which could be translated as Science and Engineering in Yoruba, Book One. In the 158-page book, all scientific and technological concepts and topics are provided in the Yoruba language. ${ }^{44}$

The attempts have stemmed into various subject matters in the Yoruba language. Take for example, A K-12 mathematics teacher, Aduke Olukemi Gbolahan (2012) came up with a series of booklets in mathematics. Titled $A B D$ Matimátíikì Alákọộệrẹ. ${ }^{45}$ In the series, Gbolahan provides mathematics in a three-book series. What all these efforts suggest is that not only is MTE possible, even what had been paraded as one of the banes of its success, that is a lack of possible published standard instructional materials, especially books, is not an insurmountable problem.

Even at a higher level of demonstrating the practical possibility of making the Yoruba language a viable medium of instruction, a whole volume of the Yoruba Studies Review was dedicated to the Yoruba language in which all

43 See Appendix 1, p.2

44 See K. J. Fakinlede, İwé İmọ İjìnle È kínni Ní E’dè Yorùbá, Kerney, NE: Morris Publishing, 2018.

45 See A. O. Gbolahan, ABD Matimátiiki Alákọộệrẹ 1-3, Ibadan: Paragon Prints and Pack Ltd., 2012. 
featured articles were written in Yoruba. If at that level of intellection knowledge production could be done in the language, there is no doubting the fact that the language could be a viable tool of instruction at all levels.

\section{Conclusion}

Elsewhere (Afolayan, 2018), we argued that "There exists the dangerous trajectory of the new generation Nigerians, which has often drifted towards anything foreign." ${ }^{26}$ MTE has become one of the collateral damages of the appetite for foreign cultures. While foreign languages are encouraged in schools, most especially European and Arabic languages, the Yoruba language and its MTE components have been pushed to the background. In all Yoruba states, there has been nowhere known for the use of the language as medium of instruction at any level. Some states, Lagos, for example, made some cheap political points when it announced its intention to make the language the language of instruction but the announcement was only effervescent and ephemeral as nothing was made of the promise beyond the level of announcements and photo ups. When the child is denied the ability to learn and express knowledge in the mother tongue, the best that child can do is to chew the cord of foreign cultures and knowledge, and all that these could do would be to give that child an amount to regurgitate foreign knowledge and cultures but not enough to creatively make something tangible, intuitive and organic in the production and reproduction of knowledge.

Hope is not lost. The ultimate hope, however, is that the attempted mother tongue education of the past would become a regular staple in the future; for it is in this model that education of the Yoruba child can become functional and relevant. Anything less will continue to be an aberration, a postmodern burden of intellectual enslavement.

\section{Bibliography}

Afolayan, Adebisi. "The Six-Year Primary Project in the Use of Yoruba as the Medium of Primary Education: A Project of the Institute of Education of the University of Ife, Ile-Ife, Nigeria, in Collaboration with the Ford Foundation, the Western State Ministry of Education, the Local School Board, and All Available Scholars of Yoruba and English Studies." Unpublished, 62 pgs, 1970.

Afolayan, M. O. "Omọ Tí A Kò Kọ́: Globalization and Cultural Education Among New Generation Nigerian Yoruba," Yoruba Studies Review, Vol 3.1, (2018): 153-172.

46 See M. O. Afolayan, "Omọ Tí A Kò Kọ: Globalization and Cultural Education Among New Generation Nigerian Yoruba," Yoruba Studies Review, Vol 3(1), 153-172. 
Asante, K. M. Afrocentricity. Trenton, NJ: Africa World Press, Inc., 1995.

Ball, J. Enhancing learning of children from diverse language backgrounds: Mother tongue-based bilingual or multilingual education in the early years. Paris: UNESCO, 2010.

Ball, Jessica. "Children Learn Better in Their Mother Tongue." Global Partnership for Education, February 21, 2014. https://www.globalpartnership. org/blog/children-learn-better-their-mother-tongue.

Benson, Carol. Girls, Education Equity and Mother Tongue-Based Teaching. Bangkok: UNESCO, 2005.

Benson, C., \& Kosonen, K. (Eds.) Language Issues in Comparative Education: Inclusive Teaching and Learning in Non-Dominant Languages and Cultures. Rotterdam: Sense Publishers, 2013.

Bradley, Olivia. "Understanding the Importance of Native-Language Instruction." The Borgen Project, October 30, 2017. https://borgenproject.org/ importance-native-language-instruction/.

Cummins, J. "Fundamental psycholinguistic and sociological principles underlying education success for linguistic minority students." In T. Skutnabb-Kangas, R. Phillipson, A. Mohanty, \& M. Panda (Eds.). Social Justice through Multilingual Education (pp. 19-35). Clevedon, UK: Multilingual Matters, 2009.

Fakinlede, K. J. İwé İmọ İjìnlè È kínní Ní Èdè Yorùbá. Kerney, NE: Morris Publishing, 2018.

Fishman, J. Language Problems of Developing Nations. New York: Wiley, 1968. Fishman, J. Readings in the Sociology of Language. The Hague, Paris: Mouton, 1968.

Gbolahan, A. O. ABD Matimátîki Alákọộbẹrẹ, İwé Kín-ín-ní. Ibadan: Paragon Prints and Pack Ltd, 2012.

Gbolahan, A. O. ABD Matimátiikì Alákọộẹèrẹ, İwé Kejì. Ibadan: Paragon Prints and Pack Ltd, 2012.

Gbolahan, A. O. ABD Matimátiiki Alákọộbẹrẹe İwé Kẹta. Ibadan: Paragon Prints and Pack Ltd, 2012.

International Development Research Association. "Why Is It Important to Maintain the Native Language?” IDRA, January 2000. https://www.idra. org/resource-center/why-is-it-important-to-maintain-the-native-language. Kioko, Angelina. "Why Schools Should Teach Young Learners in Home Language." British Council, January 16, 2015. https://www.britishcouncil.org /voices-magazine/why-schools-should-teach-young-learners-home-language.

Mercuri, Sandra Patricia. "Understanding the Interconnectedness between Language Choices, Cultural Identity Construction and School Practices 
in the Life of a Latina Educator." Gist Education and Learning Research Journal 6 (2012): 12-43.

Moll, Luis C. "Bilingual Classroom Studies and Community Analysis: Some Recent Trends." Educational Researcher 21, no. 2 (1992): 20-24.

Ologunde, A. "The Yoruba Language in Education." In Adebisi Afolayan (Ed.), Yoruba Language and Literature. Ibadan \& Ife: University Press Limited and University of Ife Press, 1982, 277-290.

Palermo, Francisco, Ariana M. Mikulski, Richard A. Fabes, Carol Lynn Martin, and Laura D. Hanish. "Cross-Language Associations and Changes in Spanish-Speaking Preschoolers' English and Spanish Academic Abilities." Applied Psycholinguistics 38, no. 2 (2017): 347-370. doi: 10.1017/ S0142716416000217.

Ruby, Mahera. "The Role of a Grandmother in Maintaining Bangla with her Granddaughter in East London." Journal of Multilingual and Multicultural Development 33, no. 1 (2012): 67-83.

Trudell, B., \& Young, C. (Eds.). (2018). Good answers to tough questions in mother tongue-based multilingual education. Dallas: SIL International. https://www.sil.org/literacy-education/good-answers-tough-questions-mother-tongue-based-multilingual-education.

Trueba, Henry T. "The Relevance of Theory on Language and Culture with Pedagogical Practices." In J. Merino, Henry T. Trueba, and Fabián A. Samaniego (eds.) Language and Culture in Learning: Teaching Spanish to Native Speakers of Spanish. Washington, D.C.: The Falmer Press, 1993.

UNESCO (2016). "If you don't understand, how can you learn?" Global Education Monitoring Report, Policy Paper 24. Paris: UNESCO.

Wallace, Lance. "What's Lost When a Language Dies." The Guardian, November 10, 2009. https://www.theatlantic.com/national/archive/2009/11/ whats-lost-when-a-language-dies/29886/. 